\title{
Heat units, solar radiation and daylength as pepper harvest predictors
}

\author{
Katharıne B Perry, ${ }^{*}$, D C Sanders ${ }^{\mathrm{d}}$, Darbie M Granberry ${ }^{\mathrm{b}}$, J Thomas Garrett $\mathrm{T}^{\mathrm{c}}$, \\ Dennıs R Decoteau ${ }^{c}$, Russell T Nagatac, Robert J Dufault ${ }^{\mathrm{d}}, \mathrm{K}$ Dean Batal ${ }^{\mathrm{e}}$, \\ Wayne J McLaurin ${ }^{\mathrm{e}}$ \\ ${ }^{\lrcorner}$Department of Horticultural Sctence North Carolina State Lniversit! Raleigh NC 27695-7609 USA \\ ${ }^{\mathrm{b}}$ Department of Extension Horticulture, Unversitl of Georgia Athens G4 30602 USA \\ 'Department of Hortculture Clemson Lniverstt' Clemson SC 29634 USA \\ ${ }^{\mathrm{C}}$ Coastal Research and Education Center Department of Horticulture Clemson Universitl 2865 Savannah \\ Highual Charleston SC 29414 L'SA \\ ${ }^{\circledR}$ Department of Horticuliure Unversitl of Georgia Tifton GA 31793 USA
}

(Recelved 3 December 1992 revision dccepted 23 February 1993)

\begin{abstract}
Dally maxımum and mınımum dır temperature, total solar radıation and daylength data from seven locations during three sedsons of 3 years were used to compare 52 htat unit accumulation models with counting days as a harvest prediction method for pepper The best model was defined as the one with the least variation, $1 \mathrm{e}$ smallest coefficient of variation (CV) CV's were calculated for each method over all seasons and locations, for each method over all locatıons for each sedson, and for each method in each season at each location In all cases hedt unit dccumulation methods were better than counting days The location and season specific model was the most accurate, but the analysis over all seasons and locations did result in smaller CV's than counting days, so improved harvest prediction can be achieved by using regionally developed models
\end{abstract}

\section{Introduction}

The tristate vegetable project 'Agricultural Adjustment in the Southeast through Alternative Cropping Systems' involves cooperators in North and South Carolina and Georgia (Bauer et al , 1989) The basic objective of the project is to analyze the feasibility of regional vegetable production providing alternatives and/or supplements to current enterprises The work described hereın was conducted to contribute to this objective

Accurate prediction of harvest date and developmental stage of a crop

${ }^{\text {*Corresponding author }}$ 
has widespread application for improving management of that crop, e $g$ schedulıng multıple harvests, pest management activities, labor and machınery Previous results (Boswell, 1929. Magoon and Culpepper, 1932, Madariagd and Knott, 1951, Katz, 1952, Guyer and Kramer, 1952, Reath and Wittwer, 1952. Gilmore and Rogers, 1958, Dufault et al, 1989, Perry and Wehner, 1990. Carlson and Hancock, 1991) have shown that heat unit modellıng for harvest date prediction has potential for operational applications Several recent publications (Perry et al , 1986. Dufault et al, 1989. Hodges, 1990) include comprehensive literature reviews of heat unit modelling The objective of this study was to determine if a method of heat unit summation could be developed to improve the accuracy of pepper (Capsicum annuum L) harvest prediction over the standard method of counting days from planting

\section{Materials and methods}

Seven locations were chosen for this study (Table 1) Spring, summer and fall plantıng dates were selected with the goal of establıshıng earliest spring and latest fall production for the tristate region (Table 2) Four cultivars of bell pepper, 'Keystone Resistant Giant No 3', 'Skıpper', 'Gator Belle' and 'Hybelle' were evaluated in each location Cultivar selection was based on commercial standards and previous yield trials Uniform plot size, experiment design, grading standards and data collection were used in all locatıons Individual plots were $61 \mathrm{~m}$ long and $15 \mathrm{~m}$ wide Two rows of 6 week old transplants were planted $30 \mathrm{~cm}$ in row and $30 \mathrm{~cm}$ between rows on $15 \mathrm{~m}$ centers A latın square experıment desıgn of cultıvars was replicated four times Commercially accepted fertilization based on soil tests, plastic mulch and pest management practices were used in all locations Half of $\mathrm{N}$ and $\mathrm{K}$ and all $\mathrm{P}$ materials were applied preplant The remainıng $\mathrm{N}$ and $\mathrm{K}$ were applied weekly Sufficient irrigation was supplied to maintain avallable soil moisture near the plants at $80 \%$ of field capacity Row middles were treated with $2 \mathrm{~kg} \mathrm{ha}^{-1}$ napromamide, and all beds were fumigated with $200 \mathrm{~kg} \mathrm{ha}^{-1}$ of 98\% methyl bromide Peppers were harvested weekly, for 4-6 weeks depending on the location, when fruits were firm and mature Cultıvars did not differ significantly in harvest date and therefore cultıvar differences were not given further consideration for calculation of heat unit accumulations Dally maxımum and mınımum air temperatures were recorded by alcohol-ınglass thermometers in standard National Weather Service wooden, doubleroofed, side-louvered shelters at $15 \mathrm{~m}$ above the surface Daily total solar radiation was measured only at Lewiston and Fletcher by a Radiometer 8-48 (Eppley Laboratory, Newport, RI) The number of days from planting to first harvest was used as the standard of comparison for summatıons of heat units 


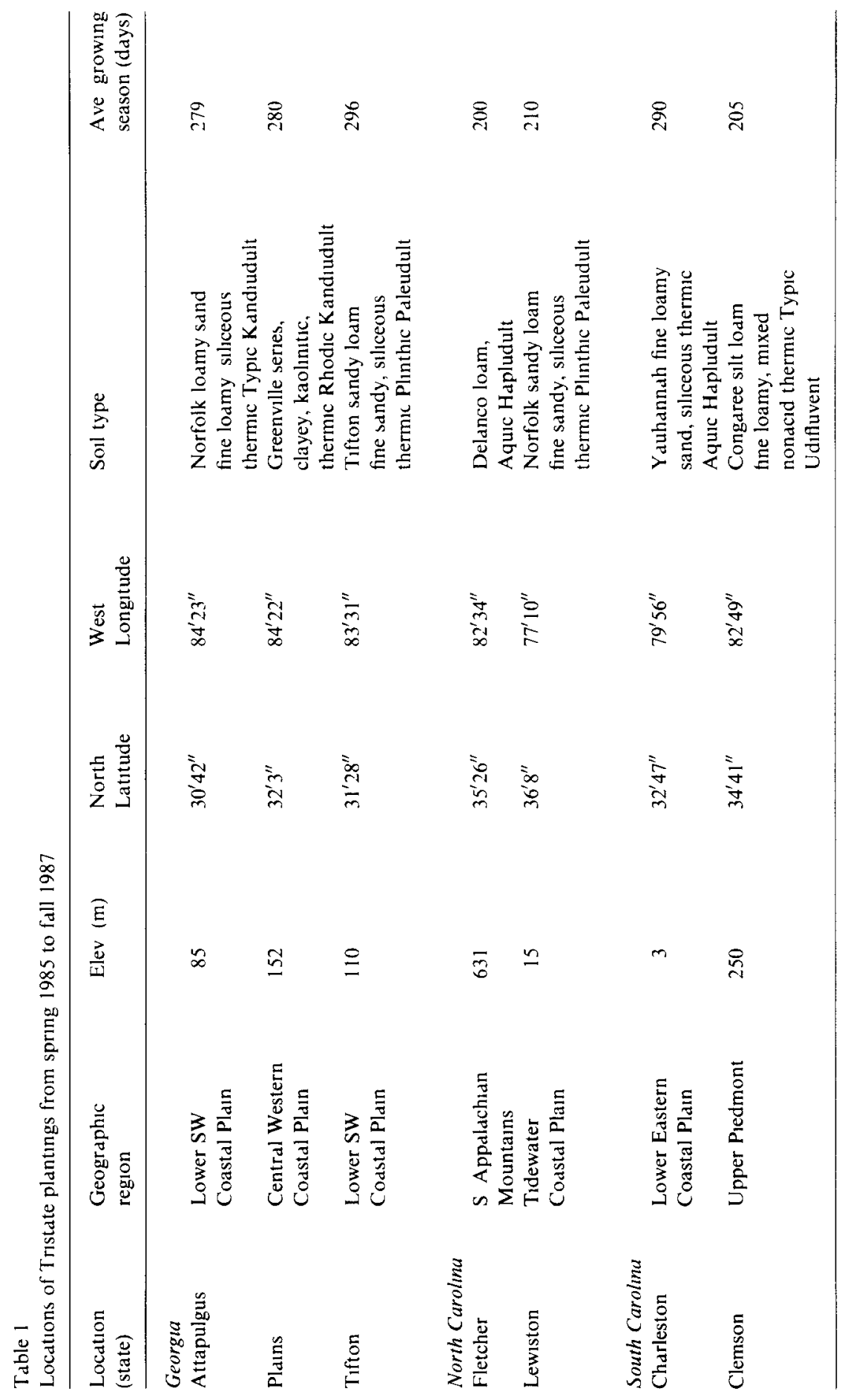


Table 2

Locations and plantıng dates of peppers from Sprıng 1985 through Spring 1987

\begin{tabular}{|c|c|c|c|c|c|c|c|c|}
\hline \multirow{2}{*}{$\begin{array}{l}\text { Planting } \\
\text { tıme }\end{array}$} & & \multicolumn{3}{|l|}{ Georgld } & \multicolumn{2}{|c|}{ North Carolind } & \multicolumn{2}{|c|}{ South Carolına } \\
\hline & & ATTA $^{b}$ & PLNS & TIFT & FLET & LEWI & CHAS & CLEM \\
\hline SPI & 1985 & & & & $15 \mathrm{Mdy}$ & $30 \mathrm{Apr}$ & & \\
\hline SP 2 & 1985 & & & & & $10 \mathrm{MdV}$ & & \\
\hline SU 1 & 1985 & & & 28 June & 3 June & & & \\
\hline SU 2 & 1985 & & & & 18 June & & & \\
\hline FL I & 1985 & $15 \mathrm{Aug}$ & & & & & 31 July & 1 Aug \\
\hline SPI & 1986 & $19 \mathrm{Mar}$ & $24 \mathrm{Mdr}$ & & $23 \mathrm{May}$ & $5 \mathrm{Mdy}$ & $1 \mathrm{Apr}$ & $18 \mathrm{Apr}$ \\
\hline SP2 & 1986 & & $9 \mathrm{Apr}$ & & & 20 Mdy & & $1 \mathrm{Mdy}$ \\
\hline SU 1 & 1986 & & & & 4 June & & & \\
\hline SU2 & 1986 & & & & 16 June & & & \\
\hline FL1 & 1986 & $18 \mathrm{Aug}$ & $12 \mathrm{Aug}$ & & & 14 July & 6 Aug & \\
\hline SP1 & 1987 & & $17 \mathrm{Apr}$ & & & 4 May & $7 \mathrm{Apr}$ & $23 \mathrm{Apr}$ \\
\hline SP2 & 1987 & & & & & 18 May & & $8 \mathrm{Mav}$ \\
\hline FLl & 1987 & & 13 Aug & & & 23 July & & \\
\hline
\end{tabular}

${ }^{\mathrm{a}}$ ATTA, Attapulgus, CHAS Charleston CLEM Clemson FLET Fletcher LEWI Lewiston PLNS, Plains TIFT, Tifton

${ }^{\mathrm{b}} \mathrm{SP}$, spring SU, summer FL, fall, 1 and 2 indicate first and second plantıngs, respectively

Heat unit summations were determined using 26 methods with 20 base/ceiling temperature combinations, where base temperatures were $0,10,14,18$ and $21^{\circ} \mathrm{C}$ and celling temperatures were $28,30,32$ and $34^{\circ} \mathrm{C}$ Base temperatures were selected to be a range around a previously determined base of $10^{\circ} \mathrm{C}$ (Sanders et al , 1980) Celling temperatures were selected to be a range above the optımum temperature for peppers, $24^{\circ} \mathrm{C}$ (Lorenz and Maynard, 1980)

Thirteen of the methods used for determining heat unit accumulation were described by Perry et al (1986) In addition, these 13 methods were multiplied by daylength These 26 methods plus the standard of counting days from plantıng to first harvest resulted in a total of 27 methods

\section{Method 1}

Standard growing degree day (GDD) computation

$\mathrm{GDD}=\Sigma\left[\left(T_{\mathrm{x}}+T_{\mathrm{n}}\right) / 2-\right.$ Base $]$

where $T_{\mathrm{x}}$ is the dally maximum and $T_{\mathrm{n}}$ is the daily minımum air temperature

\section{Method 2}

Use daily maximum instead of mean air temperature

$\mathrm{GDD}=\Sigma\left(T_{\mathrm{x}}-\right.$ Base $)$ 


\section{Method 3}

If maximum is greater than the ceiling, then set maximum equal to ceiling and use Eq (1)

\section{Method 4}

Same as Method 3, but use Eq (2)

\section{Method 5}

If maxımum is greater than the celling, set maxımum equal to the ceilıng minus the difference between the maximum and ceiling, then use Eq (1)

\section{Method 6}

If maxımum is greater than the celling, set maxımum equal to the ceiling minus the difference between the maximum and cellng, then use Eq (2)

\section{Method 7}

If maximum is greater than the celling, subtract the difference between the maximum and ceiling from the dally mean, then use $\mathrm{Eq}$ (1)

\section{Method 8}

Sum growing degree hours (GDH) by using Eq (1) for each hourly mean The hourly means used in this method were derived from the dally maximum and minımum values by the method of Perry et al (1986)

\section{Method 9}

Same as Method 8, but reset maxımum as in Method 3

\section{Method 10}

Same as Method 8, but reset maxımum as in Method 6

\section{Method 11}

Sum GDH accumulated during daytıme only 


\section{Method 12}

Same as Method 11, but reset maxımum as in Method 3

\section{Method 13}

Same as Method 11, but reset maxımum as in Method 5

Methods 14 through 26 are Methods 1 through 13 multıplied by daylength

\section{Method 27}

Number of days from plantıng through first harvest

The following additional methods were apphed only to the Fletcher and Lewiston locations

Method 28 through 53 are Methods 1 through 26 multıplied by total dally solar radiation

The coefficient of variation (CV) was used as recommended by Arnold (1959) to identify the best method for predictıng first harvest The CV is the sample standard deviation expressed as a percentage of the sample mean CV's were calculated for each method over all seasons and locations, for each method over all locations for each season, and for each method in each season at each location

\section{Results and discussion}

\section{Analysis of methods $1-27$}

Determination of the stability of Methods 1 through 27 with the 20 base/ ceiling combinations resulted in $540 \mathrm{CV}$ 's, representing 32 environments These CV's ranged from $-275 \%$ to $140 \%$ Method 19 with base $=10^{\circ} \mathrm{C}$ and celling $=30{ }^{\circ} \mathrm{C}$ had the smallest $\mathrm{CV}=135 \%$ Method 27, counting days, had a $\mathrm{CV}$ of $156 \%$ However, Method 19 showed minımal improvement over the same model without daylength, Method 6, which had a CV of $136 \%$ with base $=14^{\circ} \mathrm{C}$ and ceiling $=30^{\circ} \mathrm{C}$ Accuracy of prediction of harvest date was improved when data were analyzed on a regional basis Twenty of the remaining methods also had smaller CV's than Method 27 The five methods that did not have CV's smaller than Method 27 were Methods 1, 8, 10, 24 and 26

CV's were also determıned for all methods/base/celling combinations over the environments grouped into each of the three seasons Fall CV's (nine environments) ranged from the lowest of $52 \%$ for Method 25 base $=21^{\circ} \mathrm{C} /$ 
Table 3

Number of environments $(N)$, hedt unit dccumulation method number base and ceiling for smallest $\mathrm{CV}$ and CV for Method 27, countıng days, for sıx locations and 3 seasons during 1985, 1986 and 1987

\begin{tabular}{|c|c|c|c|c|c|c|c|}
\hline \multirow[t]{2}{*}{ Location } & \multirow[t]{2}{*}{ Sedson } & \multirow[t]{2}{*}{$N$} & \multicolumn{4}{|c|}{ Method with smallest $\mathrm{CV}$} & \multirow{2}{*}{$\begin{array}{l}\text { CV } \\
\text { Method } 27 \\
\text { Countung ddy }\end{array}$} \\
\hline & & & No & Base & Celling & CV & \\
\hline Attapulgus & Fall & 2 & 25 & 0 & 30 & 64 & 141 \\
\hline \multirow[t]{2}{*}{ Charleston } & Fall & 2 & 19 & 18 & 30 & () 04 & 46 \\
\hline & Spring & 2 & 15 & 21 & 28 & 0) 16 & 19 \\
\hline Clemson & Spring & 4 & 12 & 18 & 28 & 16 & 161 \\
\hline \multirow[t]{2}{*}{ Fletcher } & Sprıng & 2 & 2 & 0 & 34 & 002 & 67 \\
\hline & Summer & 4 & 14 & 0 & 30 & 60 & 79 \\
\hline \multirow[t]{2}{*}{ Lewiston } & Fall & 2 & 17 & 10 & 32 & 00004 & 11 \\
\hline & Sprıng & 6 & 12 & 21 & 28 & 24 & 75 \\
\hline \multirow[t]{2}{*}{ Plduns } & Fall & 2 & 12 & 21 & 32 & 007 & 173 \\
\hline & Sprıng & 3 & 6 & 0 & 28 & 68 & 57 \\
\hline
\end{tabular}

cellng $=30$ C to $535 \%$ Method 27, number of days, had a CV of $186 \%$ All methods with one or more base/ceiling combinations had smaller CV's than Method 27 Thus, certain heat unit summations were much less variable than counting days during the fall season The spring CV's (18 environments) ranged from $-107 \%$ to $239 \%$ Method 19 base $=18^{\circ} \mathrm{C} /$ celling $=30^{\circ} \mathrm{C}$ had a $\mathrm{CV}=93 \%$ compared with Method $27 \mathrm{CV}=127 \%$, 1 e heat unit summation again improved harvest date prediction accuracy over countıng days The methods that did not have CV's smaller than Method 27 were Methods 1, 10, $14,21,23,24$ and 26 The summer CV's (five environments) ranged from $-437 \%$ to $187 \%$ with Method $25 \mathrm{CV}=95 \%$ relative to Method 27 $\mathrm{CV}=201 \%$ Methods 6, 9, 12, 15, 17, 19, 22, 24, 25 and 26 also had lower CV's than Method 27 for summer

Heat unit summations showed more improvement (less variability) relative to counting days when analyzed for each season rather then over all seasons The seasonal analyses also suggest that the greater number of spring environments, 1 e 18 spring environments versus nine fall and five summer environments, likely skewed the results of the over-all-seasons analysis

Analysis for each location in each season was not possible owing to missing data where no plantıngs were made (Table 2) However, data were available to carry out ten of the 21 possible location/season combinations These showed great improvement, 1 e smaller CV's representıng less var1ability, over counting days in all cases except spring in Plains, Georgid (Table 3) Thus, using the heat unit accumulation methods at these locations during the given season should provide more accurate predictions of harvest date than using the historical average number of days from plantıng to first harvest 
Table 4

Number of environments $(N)$ and heat unit accumulation method number base and celling for smallest $\mathrm{CV}$ for three seasons at two locations during 19851986 and 1987

\begin{tabular}{|c|c|c|c|c|c|c|}
\hline \multirow[t]{2}{*}{ Location } & \multirow[t]{2}{*}{ Season } & \multirow[t]{2}{*}{$N$} & \multicolumn{4}{|c|}{ Method with smallest $\mathrm{CV}$} \\
\hline & & & No & Base & Celling & $\mathrm{CV}$ \\
\hline \multirow[t]{2}{*}{ Fletcher } & Spring & 2 & 28 & 10 & 28 & 011 \\
\hline & Summer & 4 & 32 & 14 & 30 & 68 \\
\hline \multirow[t]{2}{*}{ Lewiston } & Fdll & 2 & 43 & 14 & 32 & () 007 \\
\hline & Sprıng & 6 & 36 & 0 & 30 & 20 \\
\hline
\end{tabular}

Analysts of Methods $28-53$

The addition of radiation did not improve model prediction accuracy Analysis for each location for the avalable seasons showed that the smallest CV's determined from Methods 1-27 (Table 3) were not reduced by the addition of radiation to the models (Table 4) On the contrary, the CV's were increased in three of the four location/season combinations (Tables 3 and 4)

The limitation of radiation data from only two stations requires these results to be deemed preliminary Our results do, however, support the results of a recent study which looked at solar radiation in phenology models (Caprio and Snyder, 1991)

\section{Conclusions}

The improved model accuracy for location and season specific analysis demonstrated that a large part of the variation between locations and seasons is addressed implicitly in the location/season-specific model This is a serious weakness in heat unit modelling It means that to achieve the greatest accuracy with peppers, models must be developed for a specific site and season This would be a very costly and time consuming task However, the analyses of the methods over all seasons and locations and over all locations for each season did result in smaller CV's than merely countıng days, so improved harvest prediction accuracy can be achieved by using regionally developed models Further, the potential for improved harvest prediction using more complex models certainly exists as well

\section{Acknowledgement}

This study was funded from the USDA Grant 'Agricultural Adjustment in the Southeast through Alternative Cropping Systems' 


\section{References}

Arnold, C Y , 1959 The determination and significance of the base temperature in a linear heat unit system Proc Am Soc Hortic Sci 74 430-445

Bauer, L L, Epperson J E, Garrett J T and Sanders D C, 1989 The south Atlantic coast regetable project A multstate team approach to research on alternative farming opportunities HortScience, 24 534, 723

Boswell, V R 1929 Factors influencing y1eld and quality of peas MD Agric Exper Sta Bull, 306

Capro J M and Snyder R D 1991 Among-station andlysis of thermal and soldr-thermal phenological models for flowering of Siringa vulgarts J Am Soc Hortic Sc1 116 758-763

Carlson J D and Hancock, Jr, J F 1991 A method for determınıng suitable hedt-unit requirements for harvest of highbush blueberry J Am Soc Hortıc Scl $116774-779$

Dufault, R J Decotedu, D R, Garrett, J T, Nagata R T, Batal, K D, McLaurn, W J Granberry, D M Perry, K B and Sanders, D C 1989 Determination of heat unit requirements for collard harvest in the southeastern United States J Am Soc Hortic Sc1, 114 898-903

Gilmore E C, Jr and Rogers J S, 1958 Heat units for medsuring maturity in corn Agron J 50 $611-615$

Guyer R B and Kramer A 1952 Studies of factors dffecting the quality of green and wax beans MD Agric Exper Sta Bull, A68

Hodges, T (Editor), 1990 Predıctıng crop phenology CRC Press, Bocd Rdton, FL, 248 pp

Katz Y H 1952 The relationship between hedt unt accumulation and the planting and harvesting of canning peas Agron J , 44 74-78

Loren $\angle$ O A and Maynard D N 1988 Knott $s$ handbook for vegetable growers 3rd Edn Wiley, New York

Madariaga F J and Knott J E, 1951 Temperature summations in relation to lettuce growth Proc Am Soc Hortic Sci, 58 147-152

Magoon C A and Culpepper, C W, 1932 Response of sweet corn to varying temperatures from tıme of plantıng to canning maturity USDA Tech Bull 312

Perry K B and Wehner, T C, 1990 Prediction of cucumber harvest date using a heat unit model HortScience 25 405-406

Perry K B, Wehner, T C and Johnson, G L 1986 Comparison of 14 methods to determine heat unit requirements for cucumber harvest HortScience $21 \quad 419-423$

Reath A N and Wittwer, S H 1952 The effects of temperature and photoperiod on the development of ped varieties Proc Am Soc Hortıc Sc1, $60301-310$

Sanders, D C Kırk H J and van den Brınk, C. 1980 Growing degree days in North Carolina North Carolınd Cooperative Ext Serv Bul AG-236 Raleıgh, NC 